\title{
Editorial
}

\section{Eugenics, Heredity, and Huntington's Disease: A Brief Historical Perspective}

\author{
A. Wexler ${ }^{\mathrm{a}, \mathrm{b} *}$ \\ ${ }^{\mathrm{a}}$ UCLA Center for the Study of Women, Los Angeles, CA, USA \\ ${ }^{\mathrm{b}}$ Hereditary Disease Foundation, New York, NY, USA
}

It has often been said that almost nothing was known about Huntington's disease (HD) prior to the $1970 \mathrm{~s}$. When my mother was diagnosed with HD in 1968, my father had trouble finding a physician who knew anything about it. But if HD even today is not widely known, even within medicine, in fact the rediscovery of Mendel in 1900 drew considerable scientific attention to this disorder over a century ago. By 1908 Huntington's had attracted so much interest among neurologists and psychiatrists that the journal Neurographs devoted an entire special issue to the disease [1]. Unfortunately the social and scientific movement for "better breeding" known as eugenics-from the Greek word eugenes meaning "good in birth"-also took an interest in Huntington's [2]. Addressing the historical impact of eugenics on Huntington's disease families and on HD research can help explain the secrecy and shame that still often surrounds the illness. It can also suggest ways to move beyond this troubling inheritance in the future.

Eugenics today is often narrowly equated with the atrocities of Nazi Germany or dismissed as "pseudoscience". However for much of the 20th century, eugenic thought was an inextricable aspect of some of the most important cultural and social movements worldwide [3, 4]. The English statistician (and cousin of Darwin) Francis Galton coined the term eugenics in 1883 to mean a program of "improving" society by giving "the more suitable races or strains of blood a better chance of prevailing" [2]. In the early 20th century, when most university-based geneticists were studying Drosophila, many biologists interested in human

*Correspondence to: A. Wexler, 1930 Ocean Ave. \# 315 Santa Monica, CA 90405, USA. E-mail: arwexler@ucla.edu. heredity embraced this idea, as did other scientists, intellectuals, politicians, and physicians on all sides of the political spectrum. In the name of fostering "fitness" and eliminating the so-called "unfit" (a vague category that included the "feebleminded", racial and ethnic minorities, and those with disabilities or diseases thought to be hereditary) eugenics societies across the globe supported widely differing policies. These ranged from the genocidal extremes of Germany during the Third Reich to the immigration restrictions and compulsory sterilizations of North America, Japan, and Scandinavia to the prenatal clinics and kindergartens of France, Brazil, and Mexico [4, 5]. Clearly eugenics encompassed many meanings, as the historian Diane B. Paul explains in her authoritative history Controlling Human Heredity: 1865 to the Present [2].

As a classic Mendelian dominant disorder, Huntington's especially attracted the attention of biologists interested in human heredity. The eugenics leader Charles B. Davenport, director of the Cold Spring Harbor Biological Laboratory and an early proponent of Mendelian genetics [6], commissioned the first largescale field study of North American HD families (in 1911) and later published a widely-cited paper on the disease [7]. From the $1910 \mathrm{~s}$ through the $1930 \mathrm{~s}$, he lectured and lobbied for eugenic policies all over the world, trained field workers, and published through his Eugenics Record Office. Though more a proponent of immigration restrictions and institutionalization than of sterilization, he made a strong exception for Huntington's. Of HD he famously wrote that "a state...that does not do the obvious thing to prevent the spread of this dire inheritable disease is impotent, stupid and blind, and invites disaster" [7, 8]. 
It is unclear how many persons with HD or at risk may have been sterilized worldwide without their consent since people at risk usually had their children before their symptoms began. (In the USA, involuntary sterilizations generally occurred within state institutions for the mentally disabled, typically as a condition of release) $[9,10]$. However, Davenport and his associates helped to spread the view among clinicians that persons at risk for HD ought not to have children and if married, should be sterilized. A 1936 report issued by a distinguished committee of the American Neurological Association suggests that even critics of eugenics were likely to agree. Although the report criticized compulsory sterilization generally, the committee thought that with Huntington's, "the indications for sterilization" would usually be "obvious to the physician and should be so to the patient" [11].

Eugenics also helped give legitimacy to the notion that families with Huntington's had far more children than "normal" families; indeed early twentieth century eugenicists tended to believe that so-called "defective" families of all types were especially prolific [2]. (This latter claim was soon discredited but the relative fertility of persons with the abnormal HD gene is debated even today) [12]. More generally, eugenics encouraged negative stereotypes of all people with disabilities as "unfit", dangerous, and undesirable citizens. In this regard, two papers published in the $1930 \mathrm{~s}$ by a eugenics-minded Connecticut psychiatrist helped create a negative myth about Huntington's that was widely cited for decades $[13,14]$. According to this narrative, many USA Huntington's families traced their ancestry back to a small group of "bad characters" from seventeenth-century England who were notorious, along with their children and grandchildren, for accusations of witchcraft, inbreeding, and crime. Although this story was discredited in 1969 [15], echoes of the myth persist, for instance in Ian McEwan's 2008 best-selling novel Saturday with its thuggish brutal villain in the early stages of HD $[16,17]$.

Eugenic thinking also influenced the priorities of HD research. Even in the $1960 \mathrm{~s}$ some of the most knowledgeable geneticists and neurologists seemed to give a higher priority to research on "early detection" for eugenic purposes than to research on therapies and improved care. According to this line of thought, "the most important and pressing problem in Huntington's chorea for both the geneticist and the clinician is, undoubtedly, the identification of the genetic carrier, for this will make possible wise counseling of individuals in whose families the disease has occurred and prudent management of their personal lives [18]". The complexities posed by early detection for HD families, the psychological trauma and feelings of loss and guilt experienced by persons advised to forego childbearing or told directly to get sterilized rarely entered into medical discourse until HD family members themselves became part of the conversation [19].

It is worth recalling that some of the most sophisticated early 20th century students of Huntington's were among those who advocated the harshest measures for persons with HD and their offspring. The most nefarious was undoubtedly the German psychiatrist and professor Friedrich Panse. During the Nazi era, Panse helped authorize the sterilization and subsequently the murder of thousands of psychiatric patients and persons with disabilities, including an unknown number with Huntington's. Yet Panse was also the author of the first book-length clinical and genetic study of Huntington's families, Das Erbchorea (1942), and after World War II, served as director of a psychiatric institution in Dusseldorf, among other positions [20, 21].

Of course, many clinicians undoubtedly treated their HD patients with kindness and some wrote about the disease with compassion. Moreover, starting in the $1960 \mathrm{~s}$, social movements in many countries began to challenge eugenic ideas and legislation [22]. Feminism reframed reproduction as a private rather than a public matter. In the 1970 s sterilization laws in many countries were nullified. Greater access to birth control and safe legal abortion enabled more HD families to make their own choices about childbearing. Disability rights activists showed that appropriate social services could contribute greatly to the independence and well-being of those living with many disabilities and diseases. Perhaps it was not coincidental that grass-roots advocacy by HD families began during this decade as well! Or that clinicians who came of age in the Sixties were more willing to treat HD family members as partners.

Ironically, while most histories of eugenics mention Huntington's disease, few accounts of Huntington's mention eugenics, suggesting that we have not yet come to terms with the legacy of this movement for HD [23]. Yet the history of eugenics, in my view, underscores an important point for the HD community: while it is customary to blame stigma and discrimination on ignorance and misunderstanding, the historical record shows that in the past some of those with the most accurate knowledge-of Huntington's and other disorders-were also perpetrators of prejudice and discrimination. Scientific knowledge alone does not ensure benefit to the subjects of that knowledge. 
What does help to ensure benefit, as we know from the recent history of Huntington's, is including the voices of those most directly affected by research in the research process itself. But participation requires openness. As Marjorie Guthrie asked back in the 1970 s, "how do you get a group of people who were hiding to come forward so that you can work with real people instead of ghosts?" [19]. The secrecy and denial common even today among HD families is partly a legacy of eugenics in the past as well as a response to stigma and discrimination in the present. Creating a safe social and cultural environment for Huntington's families is one important step toward encouraging more openness about this disease. Addressing the history of eugenics is another step toward overcoming secrecy and fear and ensuring that our rapidly advancing knowledge will benefit those who need it most.

\section{REFERENCES}

[1] Neurographs. The Huntington Number. Spring; 1908.

[2] Paul DB. Controlling Human Heredity: 1865 to the Present. Amherst NY, Humanity Books; 1998.

[3] Dikotter F. Race Culture: Recent Perspectives on the History of Eugenics. American Historical Review. 1998:467.

[4] Bashford A, Levine P. The Oxford Handbook of the History of Eugenics. New York, Oxford Univ. Press; 2010.

[5] Stepan NL. The Hour of Eugenics: Race, Gender, and Nation in Latin America. Ithaca, Cornell Univ. Press; 1991.

[6] Kevles DJ. In the Name of Eugenics: Genetics and the Uses of Human Heredity. Berkeley, Univ. Calif. Press; 1985.

[7] Davenport CB, Muncey EB. Huntington's chorea in relation to heredity and eugenics. American J Insanity. 1916;73: 195-222.

[8] Wexler A. The Woman who Walked into the Sea: Huntington's and the Making of a Genetic Disease. New Haven, Yale University Press; 2008.

[9] Kline W. Building a Better Race: Gender, Sexuality, and Eugenics from the Turn of the Century to the Baby Boom. Berkeley, Univ of Calif. Press; 2001.
[10] Trent JW. Inventing the Feeble Mind: A History of Mental Retardation in the United States. Berkeley, Univ of Calif Press; 1994.

[11] Meyerson A, Ayer JB, Putnam TJ, Keeler CE, Alexander L. Eugenical Sterilization: A Reorientation of the Problem. New York, Macmillan; 1936.

[12] Harper PS. The Epidemiology of Huntington's Disease. In Bates G., Harper PS, Jones L, Huntington's Disease, 3rd ed. Oxford, Oxford Univ. Press; 2002.

[13] Vessie PR. "On the Transmission of Huntington's Chorea for 300 Years-The Bures Family Group.” J Nervous Mental Diseases. 1932;76:553-73.

[14] Vessie PR. "Hereditary Chorea: St. Anthony's Dance and Witchcraft in Colonial Connecticut." J Conn State Medical Society. 1939;3:596-600.

[15] Hans MB, Gilmore TH. Huntington's chorea and genealogical credibility. J Nervous Mental Diseases. 1969;148:5-13.

[16] Ian McEwan. Saturday. London, Jonathon Cape; 2005.

[17] Rawlins MD, Wexler NS. Prejudice in a portrayal of Huntington's disease. The Lancet. 2005;366(9491):1069-70.

[18] Myrianthopoulos NC. "Huntington's Chorea: The Genetic Problem Five Years Later.” In: Barbeau A., Advances in Neurology: Huntington's Chorea 1872-1972. New York, Raven. Press; 1973:149-59.

[19] "Public Testimony" in Report: Commission for the Control of Huntington's Disease and its Consequences. Washington D.C.: National Institutes of Health, DHEW pub. no. 78-1051: 1977. vol. 4, Pt. 5:5-250;5-325;5-35;5-71.

[20] Forsbach R. Friedrich Panse: Well established in all systems. Psychiatrist in the Weimar Republic, in the Third Reich, and in the Federal Republic of Germany. Nervenarst. 2012;83:32936.

[21] Muller-Hill B. Murderous Science: Elimination by Scientific Selection of Jews, Gypsies, and Others in Germany, 19331945. Cold Spring Harbor, Cold Spring Harbor Laboratory Press; 1998.

[22] Stern AM. Eugenic Nation: Faults and Frontiers of Better Breeding in America. Berkeley, University of California Press; 2005.

[23] Peter S. Harper has been a notable exception. See Harper PS. Opinion: Huntington's Disease and the Abuse of Genetics." Am J Hum Genet. 1992;50:460-4. 